\title{
INTERAKSI POLITIK ANTARA MUSLIM DAN NON MUSLIM MENURUT IBNU QOYYIM DAN FAHMI HUWAIDI
}

\author{
Oleh: \\ Sukandi \\ Universitas Ibrahimy Situbondo \\ Sukandy.arifin@gmail.com
}

\begin{abstract}
:
This research is intended to reveal the political relationship between Muslims and non-Muslims. According to the worldview, the political interaction between Muslims and non-Muslims are only warfare is not peaceful. Those matter because the world has seen Islam from one aspect. The study found that in politics Islam who has two interactions. The first interaction is the political interaction is revealed by Ibn Qayyim al-Jawziyyah and the second interaction was the political interaction is expressed by Fahmi Huwaidi.
\end{abstract}

Key Words: Interaksi Politik, Ibnu Qoyyim, Fahmi Huwaidi

\section{A. Pendahuluan}

Islam diturunkan oleh Allah sebagai petunjuk bagi umatnya khususnya dan manusia umumnya serta rahmat bagi alam semesta. Keberadaannya dimaksud oleh Yang Maha Pencipta untuk membawa manusia tidak hanya kepada kebahagiaan akhirat semata tetapi juga dunia ,tidak hanya untuk jiwa (rūhiyyah) namun juga raga (jasmāniyyah) dan juga tak hanya individual (fardiyyah) tetapi juga sosial kemasyarakatan (ijtimāiyyah). Seorang tokoh mesir Hasan Al-Bana mengatakan:

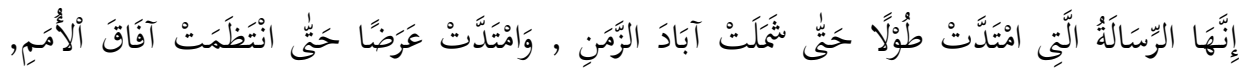

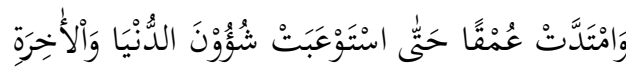

"Adalah risalah yang panjang terbentang sehingga meliputi semua abad sepanjang zaman, terhampar luas sehingga meliputi semua cakrawala umat dan begitu mendalam (mendetail) sehingga memuat urusan-urusan dunia dan akhirat"1

Karakter universal ini dalam Islam tercermin dari tidak adanya fase

1 Yusuf Qardlawi, Al-Khașaish al-'Āmmah li al-Islām (Beirut : Muassasah Al-Risālah, 1983), hlm. 105.

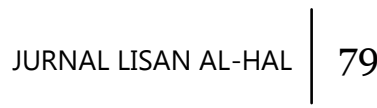


kehidupan manusia yang terlepas darinya. Dari hal-hal yang bersifat mikro sampai yang makro, disana Islam muncul baik berupa sistem (manhaj) maupun ideologi (minhāj). Termasuk diantaranya adalah sosialkenegaraan.

Dalam bernegara , Islam muncul dengan ideologi simbiotik. Sebuah faham yang memadukan antara negara (daulah) dan agama (diyānah). Menurut faham ini, negara tidak dibiarkan begitu saja dalam menjalankan kekuasaan tanpa dibarengi nilai-nilai agama. Hal ini mengacu pada konteks di zaman Rasulullah ketika mengatur sistem pemerintahan negara madinah. Hal ini ditegaskan oleh Imam Mawardi dengan ungkapan :

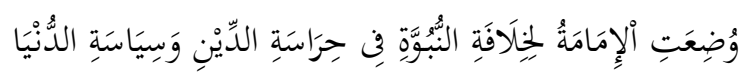

"Pemerintah diciptakan untuk menggantikan tugas Nabi dalam menjaga agama dan mengatur dunia."2

Pandangan Islam mengenai hubungan negara dan agama berbanding terbalik dengan pandangan sekuler kaum barat. Kelompok ini menjadikan antara negara dan agama dalam jalannya masing -masing. Yang profan menjadi urusan negara dan yang transenden diurus gereja. Ideologi ini bisa dilihat jelas dari pernyataan mereka:

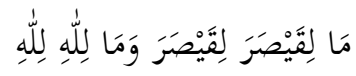

"Apa yang menjadi wilayah pemerintah adalah kewenangannya dan apa yang menjadi wilayah Allah (agama) adalah kewenangannya"3

Pandangan simbiotik oleh Islam mengenai hubungan antara negara dan agama telah menyebabkan timbulnya sebuah bentuk negara tersendiri yang dinamakan Dār al-Islām. Para ulama muslim berbeda pendapat dalam mendefinisikan Dār al-Islām .Tetapi yang menjadi titik persamaan adalah tampuk kekuasaan dipegang oleh umat Islam dan hukum-hukum Islam berlaku di dalamnya ${ }^{4}$.

Selain wajah negara baru dalam percaturan kekuatan dunia berupa Dār al-Islām, agama yang dibawa oleh Nabi Muhammad SAW ini juga memberikan nuansa wajah yang baru dalam politik bernegara yang dikenal dengan istilah al-siyāsāh al-syar'iyyah (politik islam). Para tokoh hukum Islam berbeda pendapat mengenai definisi politik Islam. Sebagian

${ }^{2}$ Ali bin Muhammad al-Mawardi Al-Ahkāmu al-Sulthāniyyah , (Beirut : Dār al-Fikr, t.th.), hlm. 5 76

3 Yusuf Qardlawi, Min Fiqh al-Daulah fi al-Islām (Kairo : Dar al-Syuruq, 1997), hlm.

4 Abdul Karim Zidan, Ahkāmu al- Żimmiyyūn wa al-Mustakminun fi dār al-Islām (Beirut : Muassasah al-Risālah, 1982 ), hlm. 18.

$80 \quad$ JURNAL LISAN AL-HAL 
ada yang agak longgar dalam mendefinisikan politik sebatas mewujudkan maslahah seperti kelompok Hanabilah dan sebagian agak ketat dimana politik tersebut harus sesuai dengan syariat Islam seperti kelompok Hanafiah dan Syafi'iyyah ${ }^{5}$.

Dengan adanya Dār al-Islām dan instrumennya al-siyāsāh alsyar'iyyah , umat Islam atas nama negara tidak hanya berinteraksi dengan sesamanya yang muslim tetapi juga dengan umat lain yang non-muslim (kafir). Interaksi ini tidak hanya dalam ranah sosial-ekonomi namun juga sosial-politik baik dalam negeri maupun luar negeri. Sejarah mencatat bahwa pada masa awal Islam, interaksi ini telah berjalan dengan adanya hubungan antara negara madinah dengan beberapa non-muslim seperti raja Habasyah ,Qaisar (raja romawi) , Kisra (raja persia), para pemimpin kafir di jazirah arab,dll6.

Hubungan antara muslim dan non-muslim dalam politik mendapatkan perhatian oleh cendikiawan muslim terdahulu (ulama salaf) dengan pengklasifikasian status mereka yang non muslim (kafir). Klasifikasi ini muncul akibat dari sifat hubungan yang muncul diantara keduanya. Setidaknya terdapat empat corak orang non-muslim dalam Islam yakni kāfir harbiy, kāfir Żimmy, kāfir mustakman ,dan kāfir mu'āhad.

Keempat golongan ini mendapatkan kebijakan tersendiri dari pemerintah Dar a-Islam. Kebijakan-kebijakan yang ditetapkan olehnya terhadap non-muslim didasarkan atas beberapa prinsip pokok. Prinsipprinsip tersebut berupa empat hal, yakni rahmah (kasih-sayang) ,mawaddah (rasa cinta) ,'adālah (keadilan) ,dan al-wafä' bil 'ahd (loyalitas). Adapun perperangan yang dilakukan negara terhadap non-muslim ( $k a \bar{f}$ fir harby) adalah semata-mata sebuah upaya untuk menghilangkan kezaliman yang telah terjadi atau berpotensi terjadi ${ }^{7}$. Allah berfirman dalam surat alMumtahanah ayat 8:

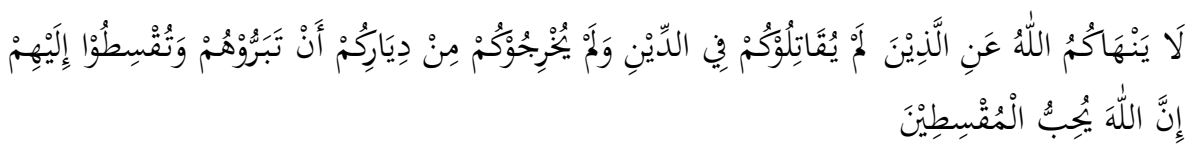

"Allah tidak melarang kamu untuk berbuat baik dan berlaku adil terhadap orang-orang yang tiada memerangimu karena agama dan tidak (pula) hlm. 203.

${ }^{5}$ Muhammad Ahmad Sahal Mahfudz, Nuansa Fiqh Sosial (Yogyakarta : LkiS, 2003),

${ }^{6}$ Wahbah Zuhaily, Al-'Alāqah al-Dauliyyah fi al-Islām (Damaskus: Dār al-Maktabi, 2000), hlm. 11.

${ }^{7}$ Muhammad Abu Zahrah, Al-'Alāqah al-Dauliyyah fi al-Islām (Kairo : Dār al-Fikr al'Arabi, 1995), hlm. 11. 
mengusir kamu dari negerimu. Sesungguhnya Allah menyukai orang-orang yang berlaku adil."

Imam al-Ṭabāriy mengatakan ," Konteks ayat ini mencakup terhadap semua pemeluk agama maupun aliran kepercayaan. Inilah pendapat yang mendekati kebenaran. Oleh karenanya selama mereka (non-muslim) tidak memusuhi dan menganiaya orang Islam ,maka umat Islam harus berlaku adil dan baik terhadap mereka. ${ }^{8 "}$

Seiring berjalannya zaman dan perubahan sistem sosial yang ada terutama sosial-kenegaraan, konsep politik Islam yang telah dirumuskan mulai dipertanyakan relevansinya. Asghar Ali Engineer mengatakan :" Di awal kemunculannya, negara Islam merupakan sebuah organisasi kolektif non-represif di kawasan arab yang semi-nomaden dan bersuku-suku. Namun dikemudian hari ia berubah menjadi negara feodal yang represif. Tidak hanya itu, perubahan juga terjadi dalam sistem pengangkatan yang pada mulanya berdasarkan terhadap pemilihan berubah menjadi jabatan raja yang turun temurun. Dalam kondisi seperti ini ,kalangan ulama harus memodifikasi teori mereka tentang negara islam agar sesuai dengan realita yang baru..$^{\prime \prime}$

Tidak hanya konsep negara yang dipertanyakan keaktualannya , tetapi juga hubungan politik antara muslim dan non-muslim dalam sebuah negara dewasa ini. Dalam politik khususnya dalam negara yang mayoritas muslim, kelompok non-muslim sering menjadi pihak yang inferior (berada di kelas kedua). Hubungan ini dinilai bersifat deskriminatif-destruktif yang tidak sesuai dengan HAM dan berpotensi menimbulkan kecemburuan dan perpecahan. Dalam Human Rights in Islamic Law disebutkan bahwa salah satu butir deklarasi HAM adalah hak untuk memperoleh keadilan dalam segala aspek termasuk politik ${ }^{10}$.

Hubungan politik tersebut juga bertolak belakang dengan fakta yang terjadi di lapangan. Di beberapa negara yang mayoritas muslim, umat non-muslim dapat menduduki posisi dalam kursi pemerintahan. Kamran Michael seorang kristen yang menjadi menteri perhubungan Pakistan, Janet Mikhail seorang kristen yang menjadi walikota Ramlah Palestina, Alees Thomas Samaan yang menjadi anggota Majelis Tinggi Parlemen

${ }^{8}$ Ibnu Jarir at-Thabari, Jāmi' al-Bayān 'an Takwil āyi al-Qurān (Beirut : Dār al-Fikr, 1995), vol.14, hlm. 84.

${ }^{9}$ Miriam Budiardjo, Dasar-Dasar Ilmu Politik (Jakarta : Prima Grafika, 2015), hlm. 240.

10 Miriam Budiardjo, Dasar-Dasar Ilmu Politik (Jakarta : Prima Grafika, 2015), hlm. 240.

82 JURNAL LISAN AL-HAL 
Bahrain, dll11.

Dari uraian ini, penulis ingin meneliti bagaimana konsep hubungan politik antara muslim dan non-muslim dalam sebuah negara menurut ulama terdahulu untuk kemudian dikontekstualisasikan dengan konsep politik modern. Karena banyaknya jumlah ulama' terdahulu dan beberapa argumen yang kuat, penulis akhirnya memilih kedua tokoh yang berbeda generasi yakni Ibnu Qayyim al-Jauziyah dan Fahmi Huwaidi untuk mewakili pandangan politik Islam di zamannya masing-masing.

Ibnu Qayyim al-Jauziyyah (w.750 H) yang bernama asli Muhammad bin Abu Bakar dikenal sebagai seorang ulama fikih Hanbāliy yang undoubted basis keilmuannya. Hal ini dapat dibuktikan dari sumbangsih besarnya kepada Islam berupa karya-karya tulis dalam berbagai cabang ilmu yang banyak dipelajari generasi sesudahnya seperti I'lämul Muwaqqi'in, Madārijus Sālikin, Zādul Ma' ād, dll. Diantara sekian banyak karya-karya beliau terdapat kitab yang bernama Aḥāmu Ahli Żimmah. Kitab ini menjelaskan mengenai ketentuan-ketentuan yang menyangkut perlakuan terhadap käfir Żimmy termasuk dalam bingkai pemerintahan .

Ibnu Qayyim dengan jelas memposisikan orang non-muslim sebagai kelas kedua dalam pemerintahan. Menurutnya orang islam dilarang untuk memberi kewenangan orang non-muslim dalam mengatur segala sesuatu yang berkenaan dengan pemerintahan negara Islam. Mewakili ulama di zamannya beliau menyatakan dalam kitab tersebut:

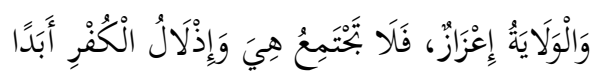

"Pemerintahan adalah sebuah kemuliaan yang tidak bisa berkumpul dengan kehinaan kufur selama-lamanya. ${ }^{12}$ "

Di zaman sesudahnya, terdapat seorang tokoh Mesir bernama Fahmi Huwaidi yang mempunyai pandangan berbeda mengenai status kafir dalam pemerintahan. Menurutnya, umat muslim dan non-muslim mempunyai derajat yang sama dalam pemerintahan sebagai sebuah warga negara. Tidak ada status Żimmy, namun yang ada hanyalah muwātanah (kewarganegaraan). Beliau berargumen:

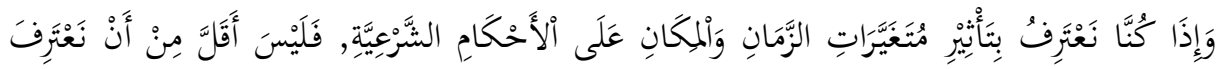

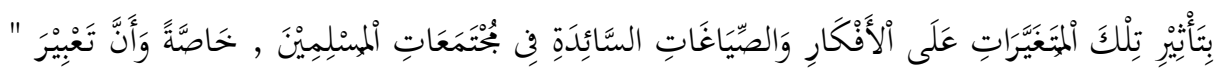

${ }^{11} \mathrm{http}: / /$ m.news.viva.co.id hlm. 499.

12 Ibnu Qayyim al-Jauziyyah, Aḥkāmu Ahli al- Żimmah (t.t. : Ramādi al-Nasyr, 1997), 


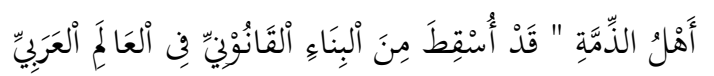

"Ketika kita mengakui adanya pengaruh waktu dan tempat terhadap perubahan hukum syariat, maka kita pun harus mengakui adanya pengaruh keduanya terhadap perubahan akan ide dan bentuk-bentuk kepemimmpinan dalam masyarakat muslim. Lebih-lebih ungkapan " Ahlu al- Żimmah "yang telah hilang dalam undang-undang dunia arab. ${ }^{13}$ "

Dari kedua pendapat diatas ,penulis ingin mengelaborasi konsep interaksi politik antara muslim dengan non-muslim dalam sebuah negara islam. Dan juga alasan-alasan yang mendasari keduanya dalam merumuskan konsep tersebut sehingga menjadi jelas dalam konteks apa pernyataan keduanya muncul. Dalam kajian ini akan dijelaskan mengenai: 1) pandangan Ibnu Qayyim al-Jauziyyah mengenai interaksi politik muslim dengan non-muslim dan 2) Pandangan Fahmi Huwaidi mengenai interaksi politik muslim dengan non-muslim.

\section{B. Metode Penelitian}

Sebuah penelitian harus bisa dipertanggungjawabkan validitasnya. Oleh karena itu diperlukan metode-metode yang dapat digunakan selama penelitian berlangsung sehingga dapat memperoleh data yang benar. Penelitian ini merupakan jenis penelitian kualitatif deskriptif yaitu penelitian dengan menggunakan studi teks atau pustaka yaitu studi pustaka yang lebih memerlukan olahan filosofik dan teoritik daripada empirik. Studi ini menginformasikan kepada pembaca tentang hasil-hasil penelitian lain yang berkaitan erat dengan penelitian yang dilakukan saat itu ,menghubungkan penelitian dengan literatur-literatur yang ada ,dan mengisi celah-celah dalam penelitian sebelumnya.

Dalam melakukan analisis data penulis menggunakan pendekatan interpretasi teks (penafsiran makna teks) atau philological approach (pendekatan filologi) atau fahmu al-nushüsh (pemahaman terhadap teks). Yaitu dengan mengklasifikasi teks, menguji otentitas, kepengarangan, menyunting bagian-bagian yang dianggap kabur, memberikan penjelasan dan penafsiran dan meneliti hubungan antar-teks itu sendiri.

${ }^{13}$ Fahmi Huwaidi, Muwāthinūn la Żimmiyyūn (Kairo: Dār al-Syurūq, 1990), hlm. 126.

84 JURNAL LISAN AL-HAL 


\section{Kajian Teoritik}

1. Interaksi Politik

Interaksi Politik berasal dari dua kata yaitu interaksi dan politik. Interaksi berasal dari bahasa inggris interaction (kata benda dari interact) yang mempunyai dua makna, yakni saling memberikan dampak antara dua pihak (have an effect on each other) atau komunikasi dan bekerja sama (communicate and work together). Dalam Kamus Besar Bahasa Indonesia, Interaksi berarti hal saling melakukan aksi, berhubungan, mempengaruhi, dan antar hubungan ${ }^{14}$.

Sedangkan kata politik, pada awalnya bermakna sebuah usaha untuk mencapai masyarakat politik yang baik. Namun, dewasa ini istilah politik diidentikkan dengan masalah pemerintahan (government), seperti kekuasaan, kebijakan, pembuatan keputusan, alokasi nilai, dsb ${ }^{15}$.

Oleh karena itu, politik adalah hal-hal yang berhubungan dengan pemerintahan, lembaga-lembaga, proses-proses politik, pressure groups, hubungan-hubungan internasional, dan tata pemerintahan yang dilakukan secara perorangan maupun kelompok ${ }^{16}$. Dalam Islam kata politik diungkapkan dengan kata ' siyāsah '. Dalam bahasa arab kata 'siyāsah' berasal dari kata kerja "sāsa yasūsū " yang bermakna menegakkan sesuatu dengan segala yang bermanfaat baginya ${ }^{17}$.

Secara terminologi, kata siyāsah memiliki dua definisi. Definisi pertama adalah definisi yang dibuat oleh pakar Islam terdahulu sedangkan definisi kedua merupakan definisi yang dibuat oleh ulama kontemporer. Menurut pakar islam terdahulu, siyāsah adalah pengetahuan mengenai segala keadaan mengenai kebijakan pemerintah dan sosial kemasyarakatan, semisal keadaan para sultan (salāți>n), raja (mulūk), amir (umarā'), ahli keuangan (ahlu al-iḥtisāb), hakim (hukamā'), cendekiawan ('ulamā'), wakil lembaga keuangan negara (wukalä' bait al$m \bar{a} l$ ), distributor keuangan Negara (wuzarā' bait al-māl), dan semisalnya. Hal ini mengacu pada beberapa karangan ulama terdahulu semisal alisyārah fi> ādābi al-wizārah dan sirāj al-mulūk karya al-Tartusi, nași>hatu al-mulūk karya al-Ghazali, al-aḥkām al-sulțāniyyah karya al-Mawardi, dll.

\footnotetext{
${ }^{14}$ Oxford University Press, Oxford Learner's Pocket Dictionary (t.t. : t.p. t.th), hlm. 232.

15 Miriam Budiardjo, Dasar-Dasar Ilmu Politik (Jakarta : Prima Grafika, 2015), hlm. 14.

16 Hassan Shadily, Ensiklopedi Indonesia (Jakarta : PT. Dai Nippon Gitakarya Printing, 1984), vol. 5, hlm. 2739

17 Muhammad bin Mukran al-Anshari, Lisānul 'Arab ( Beirut : Dār al-Kutub al'Ilmiyyah 2003), vol. 6, hlm. 131
} 
Namun dalam konteks sekarang, para pakar Islam mendefinisikan siyāsah sebagai sebuah nama bagi ketentuan-ketentuan dan kebijakankebijakan dalam mengatur keadaan masyarakat baik menyangkut pemerintahan, perundang-undangan, maupun peradilan. Disamping juga yang menyangkut kekuasaan eksekutif maupun administratif serta hubungan bilateral atau multilateral dengan bangsa-bangsa yang lain ${ }^{18}$. Oleh karena itu, yang dimaksud interaksi politik adalah sebuah hubungan baik berupa komunikasi atau kerjasama diantara dua pihak atau lebih dalam segala sesuatu yang menyangkut pemerintahan.

\section{Prinsip Interaksi Politik Dalam Islam}

Islam datang dengan ideologi perpaduan antara agama dan negara, Oleh karenanya, Islam mempunyai watak tersendiri dalam berpolitik. Politik dalam Islam tidak hanya berorientasi terhadap kestabilan masyarakat di dunia melainkan juga sarana untuk menjaga eksistensi Islam di muka bumi. Dalam berpolitik Islam mempunyai beberapa prinsip dasar $^{19}$ :

\section{a. Keadilan (al-'adlu) dan kesetaraan (al-musāwah)}

Keadilan dan kesetaraan adalah dua hak diantara beberapabeberapa hak manusia yang diberikan oleh Allah SWT bagi tiap-tiap hambanya tanpa terkecuali.

Pada tataran ideologi dan praktek, Islam sangat menjunjung tinggi keadilan dan membumikannya kedalam segala ajarannya. Dalam Al-Qur'an dijelaskan :

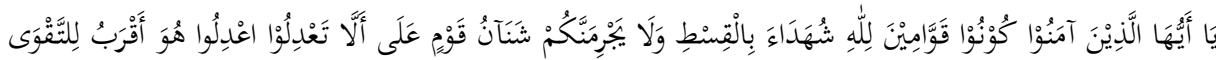

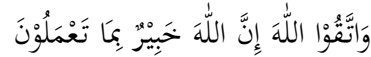

"Hai orang-orang yang beriman hendaklah kamu jadi orang-orang yang selalu menegakkan (kebenaran) karena Allah, menjadi saksi dengan adil. Dan janganlah sekali-kali kebencianmu terhadap sesuatu kaum, mendorong kamu untuk berlaku tidak adil. Berlaku adillah, karena adil itu lebih dekat kepada takwa. Dan bertakwalah kepada Allah, sesungguhnya Allah Maha Mengetahui apa yang kamu kerjakan." (QS: Al-Maidah :8)

Berbeda dengan Islam, masyarakat non-muslim semisal

18 Muhammad Zakariyya al-Nadaf, Al-Akhlāq al-Siyāsiyah (Damaskus : Dār alQalam 2006), hlm. 22.

19 Abdul Aziz 'Izzat al-Khayyath, Al-Nidzām al-Siyāsi fi al-Islām (Kairo : Dār alSalām 1999), hlm. 83 
masyarakat yunani, romawi, persia, dsb hanya menggemborkan nilai-nilai keadilan tanpa adanya implementasi yang riil. Masyarakat Yunani telah membuat beberapa hak bagi tiap-tiap warga negara yang dikenal dengan "wațniyyah". Namun dalam kenyataannya, hak tersebut hanya berlaku bagi orang-orang Yunani dan tidak bagi selainnya. Sementara orang romawi, mereka telah membuat sebuah peraturan bahwa hak kepemimpinan hanya ada bagi golongan tertentu, namun kewajiban untuk patuh dan tunduk adalah bagi semua golongan yang menetap disana.

Kesetaraan dalam Islam tidak hanya diterapkan kepada para pemeluknya melainkan juga kepada para pemeluk agama lain. Keadilan muncul karena adanya kesetaraan manusia. Dalam hadist, Rasulullah menegaskan bahwa islam memandang semua manusia adalah sama. Yang membedakan hanyalah rasa takut mereka terhadap Tuhan. Rasulullah bersabda ${ }^{20}$ :

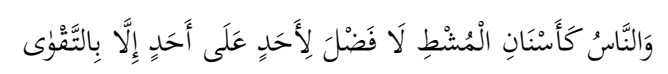

"Manusia bagaikan gigi-gigi sisir rambut. Tidak ada keistimewaan bagi seseorang melebihi orang lain kecuali dengan takwanya."

\section{b. Musyawarah (al-syūrā) dan keberagaman (al-ta'addudiyyah)}

Kata musyawarah diambil dari kata syawara yang berarti mengeluarkan madu dari sarang lebah. Kosa kata ini kemudian berkembang pemaknaannya sehingga mencakup terhadap segala sesuatu yang dapat diambil dan dikeluarkan dari yang lain (termasuk pendapat). Kata musyawarah juga dapat bermakna mengatakan atau mengajukan sesuatu dan pada dasarnya kata musyawarah digunakan untuk hal-hal yang baik, sejalan dengan makna dasarnya ${ }^{21}$.

Islam sangat menekankan sistem musyawarah dalam tiap-tiap sendi kehidupan umat Islam. Adanya musyawarah adalah untuk membicarakan segala sesuatu yang belum ada penjelasan secara gamblang dan pasti dari agama, termasuk dalam urusan politik-kenegaraan. Nabi Muhammad SAW sering meminta pendapat sahabatnya dalam memutuskan seseuatu yang berkenaan dengan urusan masyarakat dan negara semisal lokasi pasukan Islam pada saat perang badar dan kasus penfitnahan Siti ‘Aisyah.

20 Muhammad al-Shan'ani, Subul al-Salam (Kairo: Maktabah al-Iman, t.th.), vol. 3, hlm. 210. 469.

21 M.Quraish Shihab, Wawasan Al-Quran (Bandung : Penerbit Mizan, 2004), hlm. 
Dalam Al-Qur'an, Allah secara tegas memerintahkan Nabi Muhammad SAW untuk bermusyawarah . Allah berfirman dalam surat Ali Imran ayat 159 :

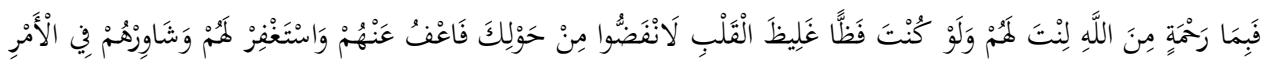

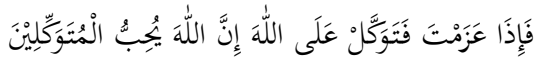

"Maka disebabkan rahmat dari Allah-lah kamu berlaku lemah lembut terhadap mereka. Sekiranya kamu bersikap keras lagi berhati kasar, tentulah mereka menjauhkan diri dari sekelilingmu. Karena itu maafkanlah mereka, mohonkanlah ampun bagi mereka dan bermusyawarahlah dengan mereka dalam urusan itu. Kemudian apabila kamu telah membulatkan tekad, maka bertawakkallah kepada Allah. Sesungguhnya Allah menyukai orang-orang yang bertawakkal kepada-Nya."

Musyawarah adalah bukti dari keberagaman yang ada pada masyarakat dalam berbagai hal. Keberagaman adalah sesuatu yang pasti dan merupakan sunnatullah, baik berupa keberagamaan yang menyangkut lahir manusia seperti warna kulit, postur tubuh, dst. maupun yang menyangkut rasa batin manusia seperti kepercayaan dan agama. Hal ini telah dikatakan oleh Al-Qur'an dalam surat Al-Hujurat ayat 13 dan surat Yunus ayat 99 yang berbunyi:

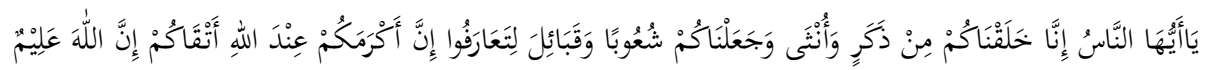

"Hai manusia, sesungguhnya Kami menciptakan kamu dari seorang laki-laki dan seorang perempuan dan menjadikan kamu berbangsa-bangsa dan bersuku-suku supaya kamu saling kenal-mengenal. Sesungguhnya orang yang paling mulia diantara kamu disisi Allah ialah orang yang paling taqwa diantara kamu. Sesungguhnya Allah Maha Mengetahui lagi Maha Mengenal"

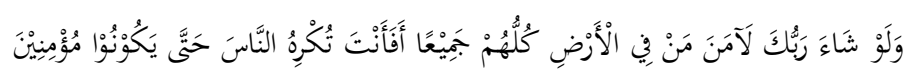

"Dan jikalau Tuhanmu menghendaki, tentulah beriman semua orang yang di muka bumi seluruhnya. Maka apakah kamu (hendak) memaksa manusia supaya mereka menjadi orang-orang yang beriman semuanya “

Keberagaman yang ada dalam masyarakat dapat dikelompokkan menjadi tiga. Pertama, al-ta'addudiyyah al-ijtimā'iyyah (keberagaman sosial) ialah keberagaman kelompok masyarakat yang berbeda secara kebudayaan pada wilayah yang berbeda semisal pertanian, perdagangan, 
industri, dll. Sebagai contoh, orang jawa pada ranah pertanian, orang Madura pada ranah penangkapan ikan, orang Sumatra pada ranah perkebunan, dll. Termasuk kategori ini adalah sekelompok masyarakat yang mempunyai tradisi yang sama namun dengan keyakinan yang berbeda.

Kedua, al-ta'addudiyyah al-fikriyyah (al-idilūjiyyah) (keberagaman pemikiran) adalah keberagaman masyarakat dalam ideologi yang dianut. Ideologi ini bisa berupa nilai-nilai filsafat, pemikiran sosial, pemikiran ilmiah, maupun pemikiran politik.

Ketiga, al-ta'addudiyyah al-'irqiyyah (keberagaman suku dan ras) adalah keberagaman yang didasarkan atas suku, warna kulit, ras, dan tempat tinggal. Keberagaman ini tidak melihat dari aspek kepercayaan, atau ideologi yang dianut. Contohnya ialah orang arab di timur tengah, orang prancis di Eropa, orang cina di Asia, dan orang negro di Afrika.

\section{c. Kepatuhan kritis (al-thā'ah al-wä'iyyah)}

Salah satu prinsip islam dalam berpolitik adalah ketaatan kepada negara/pemimpin. Sifat patuh ini tidak bersifat mutlak sehingga mengganggap bahwa segala yang dilakukan oleh pemimpin adalah benar. Namun, kewajiban patuh kepada pemimpin adalah selama tidak dalam hal kemaksiatan. Allah berfirman dalam surat al-Nisa' ayat 59 :

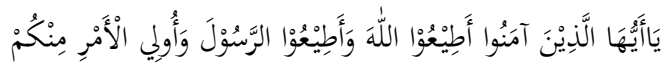

"Hai orang-orang yang beriman, taatilah Allah dan taatilah Rasul (Nya), dan ulil amri di antara kamu. "

Quraisy Shihab mengatakan bahwa tidak disebutkannya kata taat kepada ulil amri untuk memberi isyarat bahwa ketaatan kepada mereka tidak berdiri sendiri tetapi bersyarat dengan ketaatan kepada Allah dan Rasul-Nya ${ }^{22}$. Selain itu Rasulullah juga bersabda:

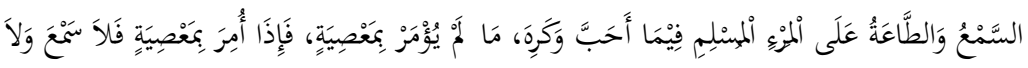

$$
\begin{aligned}
& \text { طَاعَة }
\end{aligned}
$$

" Seorang muslim harus patuh dan tunduk terhadap apa yang ia senangi atau yang ia benci (pemerintah) selama tidak dalam hal kemaksiatan. Oleh karenanya, apabila dalam hal kemaksiatan maka tiada kepatuhan dan 427.

22 M.Quraish Shihab, Wawasan Al-Quran (Bandung : Penerbit Mizan, 2004), hlm. 
ketundukan ialah wajib.23" Kepatuhan yang diajarkan oleh Islam adalah kepatuhan dengan kesadaran bukan kepatuhan yang membabi-buta seperti kepatuhan orang-orang dahulu kepada raja-raja mereka.

\section{d. Pengawasan objektif (al-murāqabah al-aminah)}

Dalam pemerintahan, Islam memperbolehkan rakyat untuk melakukan koreksi terhadap kebijakan maupun sistem pemerintah yang ada. Pengawasan ini harus didasari dengan objektivitas yang tulus bukan untuk mencari kepopuleran maupun merusak pemerintahan. Adanya kebolehan ini berdasarkan pada firman Allah :

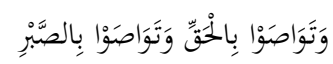

"dan nasehat menasehati supaya mentaati kebenaran dan nasehat menasehati supaya menetapi kesabaran."

Allah SWT memerintahkan hamba-hambanya untuk saling berwasiat tentang sesuatu yang haq. Yakni, saling menasehati dan mendorong untuk mengesakan Allah, membumikan Al-Qur'an, amar makruf nahi munkar, dan mengajak kepada agama dan petuah. Sayyidina umar pernah berdoa:

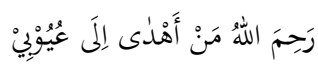

"Semoga Allah memberikan rahmat-Nya kepada orang yang mengingatkan aib-aibku"24"

Kegiatan pengawasan ini sangat penting untuk meluruskan pemerintah manakala ia berbuat lalim sehingga mengabaikan hak-hak warga negara semisal money laundering, korupsi, kolusi, nepotisme, dll. Ketika pengawasan kepada pemerintah ditiadakan, maka bisa dipastikan akan terjadi kehancuran dan kebinasaan sebuah negara. Rasulullah SAW bersabda:

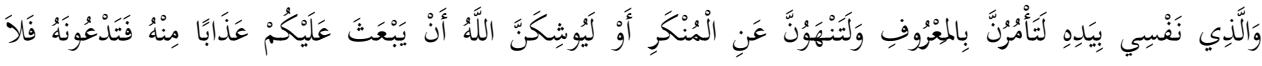

$$
\begin{aligned}
& \text { يَسْنَجِيْبَ لَكُمْ }
\end{aligned}
$$

“ Demi Dzat yang diriku ada pada kekuasaan-Nya. Niscaya kalian semua menyuruh kepada kebaikan dan melarang dari keburukan atau hampir saja Allah mengirimkan azab sehingga kalian semua meminta kepada-Nya

${ }^{23}$ Ahmad bin Hajar al-'Atsqalani , Fathul Bāri bi Syarḥ Șaḥị̣ Bukhāri (Beirut : Dar al-Fikr 2000), vol. 15, hlm. 16.

${ }^{24}$ Wahbah al-Zuhaili, al-Tafsir al-Munir (Damaskus : Dār al-Fikr, 2011), vol. 15, hlm. 792.

90 JURNAL LISAN AL-HAL 
namun tak dikabulkan oleh-Nya ${ }^{25 "}$

\section{Kategori Muslim dan non-Muslim a. Definisi Muslim}

Secara bahasa, yang disebut orang muslim atau umat islam adalah mereka yang beragama Islam. Namun begitu, secara teoritis terdapat banyak perbedaan pendapat mengenai siapa yang bisa dikategorikan orang islam. Abu al-Qasim Al-Ka'biy berpendapat bahwa yang dimaksud orang islam adalah mereka yang meyakini kenabian Muhammad SAW dan membenarkan segala ajarannya. Kelompok Karāmiyyah mengatakan bahwa seseorang bisa dikatakan muslim apabila ia berikrar dengan dua kalimat sahadat. Ada juga sebuah golongan yang mengatakan, apabila orang islam adalah mereka yang meyakini kewajiban salat ke kakbah yang berada di Makkah. Pendapat ini disetujui oleh kelompok fuqahā hijaz, sekalipun menurut fuqahā kūfah hal ini adalah salah. Sedangkan menurut Abu Mansur al-Bagdadi, orang islam adalah mereka yang memiliki beberapa sifat, yakni : 1) meyakini sifat baru (hudūś) pada alam; 2) meyakini bahwa tuhan adalah esa, dahulu (qidam), tidak ada yang menyerupai, adil, bijaksana, dan memiliki sifat-sifat tertentu; 3) meyakini kenabian Muhammad SAW, meyakini segala yang dibawanya, sifat universal dan eksistensi syariatnya di segala masa; 4) meyakini bahwa Alquran adalah sumber hukum dan, 5) meyakini kewajiban menghadap ke kakbah pada tiap-tiap salat.

\section{b. Definisi Non-Muslim}

Di sisi yang lain, orang-orang yang tidak masuk ke dalam kategori muslim secara otomatis dikatakan sebagai orang kafir / non-muslim. Dalam konteks negara islam, orang-orang non-muslim diklasifikasi kedalam 3 kelompok: Pertama, Kafir Żimmiy. Kafir Żimmiy adalah orangorang non-muslim yang melakukan perjanjian dengan orang Islam (dalam hal ini dilakukan oleh pemimpin atau wakilnya) untuk tinggal di wilayah Islam dengan kompensasi berupa kewajiban membayar jizyah sebagai ganti dari keamanan mereka ${ }^{26}$.

${ }_{25}^{25}$ Muhammad bin 'Isa, Sunan al-turmudzi ( Beirut: Dār al-Fikr 1994) hlm. 69. Vol 4.

26 Wahbah al-Zuhaili, Al-Fiqh al-Islāmi wa Adillatuhū (Damaskus : Dar al-Fikr, 2004), vol. 8 hlm. 5879. 
Para ulama berbeda pendapat tentang orang-orang non-muslim yang boleh melakukan perjanjian damai tersebut ('aqad Żimmah). Kalangan Syāfi'iyyah berpendapat bahwa orang non-muslim yang boleh melakukannya adalah orang yahudi, nasrani, majusi, para penganut agama sebelum Islam, keturununan ahli kitab, dan orang yang menduga dirinya termasuk salah satu diantara mereka yang boleh melakukan 'aqad Żimmah. Oleh karena itu, orang-orang non muslim selain diatas tidak boleh melakukan 'aqad Żimmah melainkan harus masuk Islam atau diperangi seperti para penyembah berhala, filosof, ateis, dan semisalnya.

Sedangkan menurut kelompok Hanafiyyah, semua orang musyrik masuk kedalam kategori tersebut tak terkecuali para penyembah berhala dengan syarat ia berasal dari luar arab. Pendapat yang agak longgar dikemukakan oleh kelompok Mālikiyyah yang memutlakkan 'aqad Żimmah bagi semua non-muslim kecuali yang berasal dari suku Quraisy27.

Selain membayar jizyah, orang-orang kafir Żimmiy juga dikenakan beberapa kewajiban lain dalam kehidupan mereka di tengah-tengah orang-orang muslim. Kewajiban tersebut berupa: 1) Mengikuti aturanaturan Islam yang berkenaan dengan hubungan sosial-kemasyarakatan (mu'āmalah); 2) Tidak mencela atau menghina segala sesuatu yang berhubungan dengan agama Islam seperti Alquran-hadist, pribadi Rasulullah, dll; 3) Tidak melakukan kegiatan yang dapat memberikan bahaya (darar) bagi umat Islam setempat seperti pemberontakan, pembangunan gereja atau rumah-rumah ibadah, menampakkan ajaranajaran mereka seperti mengonsumsi arab dan babi, dll; 4) Memakai atribut yang membedakan mereka dari orang-orang Islam seperti memakai ghiyār dan zunnār (sabuk) dan 5) Tidak boleh menunggang kuda dan berjalan di jalan tersendiri yang sempit ketika jalan penuh sesak oleh orang muslim ${ }^{28}$.

Kedua, Kafir Mustakman. Kafir Mustakman adalah orang kafir harbiy yang meminta perjanjian untuk tidak dibunuh. Dengan adanya akad amān bagi seorang kafir harbiy, maka ia tidak boleh dibunuh, anak dan istrinya tidak boleh ditawan, dan hartanya tidak menjadi harta rampasan. Selain itu, seorang kafir mustakman tidak dikenakan kewajiban membayar jizyah sebagaimana kafir Żimmiy.

Masa akad amān bagi seorang kafir harby adalah kurang dari satu tahun. Hal ini karena dikhawatirkan jikalau mereka akan menjadi mata-

27 Abdurrahman bin Muhammad Ba'alawi, Bughyah al-Mustarsyidin (Beirut : Dar al-Kutub al-Ilmiyyah, 2013), hlm. 316.

${ }_{28}$ Abdul Qahir al-Baghdadi, Al-Farqu Baina al-Firāq (Kairo : Maktabah Ibnu Sinā, t.th.), hlm. 29.

92 JURNAL LISAN AL-HAL 
mata musuh. Sebelum satu tahun, imam akan memberikan penawaran supaya ia membayar jizyah sehingga ia berstatus sebagai kafir Żimmy atau kembali ke wilayah kafir harbiy.

Para ulama berbeda pendapat mengenai status akad amān ini. Golongan Hanafiyyah mengatakan bahwa akad ini tidak mengikat sehingga sewaktu-waktu imam boleh membatalkannya. Sedangkan mayoritas ulama syi>'ah imāmiyyah, dan zaidiyyah mengatakan bahwa akad tersebut bersifat mengikat sehingga akad ini tidak boleh dibatalkan kecuali terdapat sebuah bahaya ${ }^{29}$.

Ketiga, Kelompok murtaddin. Kelompok murtaddin adalah mereka yang melakukan tindakan riddah, yakni memutus ikatan dari mengikuti agama islam baik hanya sekedar niat, perkataan, maupun perbuatan kekufuran secara mutlak (baik sekedar bermain-main / benar-benar ingkar). Terdapat banyak sekali perbuatan, perkataan, maupun keyakinan yang menjadikan seseorang dikategorikan murtad. Sebagai contoh ialah mengingkari adanya tuhan, para utusan-Nya, menghalalkan sesuatu yang haram secara konsensus.

Sedangkan dalam dār al-harbi (negara kafir), golongan non-muslim dikelompokkan menjadi 6 golongan ${ }^{30}$ :

1) Ahli Kitab. Ahli kitab adalah mereka yang membantu kepada agama asbāt (segolongan dari kaum yahudi). Sebagian besar anggota ahli kitab terdiri dari umat Yahudi dan Nasrani. Kelompok ini berpegang kepada kitab taurat yang diturunkan kepada Nabi Musa. Sekalipun umat nasrani memiliki kitab injil, namun didalamnya tidak terdapat aturanaturan syariat. Injil hanya memuat rumus-rumus, perumpamaanperumpamaan, dan nasehat-nasehat ${ }^{31}$.

2) Golongan Shābiah. Para ulama berbeda pendapat mengenai golongan ini. Menurut Abu Hanifah dan Hanābilah golongan shabiah termasuk ahli kitab. Mereka beriman terhadap kitab tuhan, membaca kitab zabur dan tidak menyembah berhala. Sementara menurut Imam Abu Yusuf dan Muhammad bin Hasan, golongan ini tidak termasuk ahli kitab karena mereka adalah penyembah bintang-bintang ${ }^{32}$.

${ }^{29}$ Wahbah al-Zuhaili, Al-Fiqh al-Islāmi wa Adillatuhū (Damaskus : Dār al-Fikr, 2004), vol. 8, hlm. 5869.

30 Yahya bin Syaraf al-Nawawi ,Minhāju al-Thālibin wa 'umdah al-Muftin (Beirut : Dār al-Kutub al-'Ilmiyyah 2011). hlm.170. hlm. 169.

31 Abdul Karim al-Syahrastani, Al-Milal wa al-Nihal (Beirut : Dār al-Fikr, 2005),

32 Wahbah al-Zuhaili, Al-Fiqh al-Islāmi wa Adillatuhū (Damaskus : Dār al-Fikr, 2004), vol. 9, hlm. 6657. 
3) Golongan Majūsi. Golongan majūsi adalah golongan yang meyakini bahwa alam ini berasal dari dua zat. Asal pertama adalah cahaya yang termanifestasikan kedalam kebaikan, manfaat, dst (segala yang baik) dan asal kedua adalah kegelapan yang termanifestasikan kedalam keburukan, bahaya, dst (segala yang buruk) ${ }^{33}$.

4) Golongan Musyrikun. Golongan musyrikun adalah golongan yang meyakini ketuhanan Allah, namun mereka mensekutukannya, semisal penyembah berhala.

5) Golongan Dahriyyah. Golongan Dahriyyah adalah golongan yang tidak meyakini Tuhan. Mereka berkeyakinan bahwa alam ini ada dengan sendirinya. Kehidupan dan kematian disebabkan oleh waktu ( $d a h r)$.

6) Golongan yang menafikan adanya rasul. Golongan ini adalah kelompok yang meyakini adanya pencipta, terciptanya makhluk dan hari kebangkitan. Akan tetapi, mereka mengingkari adanya rasul dan menyembah berhala-berhala. Mereka menyakini bahwa berhalaberhala tersebut dapat memberikan pertolongan di hari kiamat.

\section{Pembahasan}

\section{Biografi Ibnu Qayyim al-Jauziyyah}

Nama lengkap beliau adalah Abu Abdillah Syamsuddin Muhammad bin Abu Bakar bin Ayyub bin Hariz bin Makki al-Zar'i al-Dimasyqi alHanbali. Beliau terkenal dengan nama Ibnu Qayyim al-Jauziyyah. Julukan Ibnu Qayyim didapatkan, karena ayah beliau adalah pengurus sebuah sekolah yang bernama al-Jauziyyah di daerah Damaskus. Ibnu Qayyim dilahirkan pada tanggal 7 Safar tahun $691 \mathrm{H}$ di Damaskus. Ayah beliau terkenal sebagai seorang syekh yang saleh dan rajin beribadah.

Perjalanan mencari ilmu dimulai ketika beliau berumur 7 tahun, yakni kepada Imam al-Syihab al-'Abiry (w.697). Diantara guru-guru beliau ialah Ibnu Taimiyyah (guru beliau dalam fikih), Ibnu 'Abdi al-Daaim, Ibnu Muflih (guru yang selalu dimintai pertimbangan), al-Ba'labakki Abu alFath (guru dalam fikih dan sastra arab), al-Majd al-Harani (guru dalam faraid, fikih, dan ushul fikih), al-Shafdi al-Hindi (guru beliau dalam tauhid dan ushul fikih), dll.

Dari beberapa guru, beliau menguasai beberapa disiplin ilmu seperti tafsir, hadist, fikih, ushul fikih, nahwu, faraid, tasawwuf dll. Penguasaan beliau terhadap berbagai macam ilmu telah diakui oleh banyak ulama. Diantaranya: 1) Imam Suyuti mengatakan, " Ibnu Qayyim hlm. 188.

33 Abdul Karim al-Syahrastani, Al-Milāl wa al-Nihāl (Beirut : Dār al-Fikr, 2005),

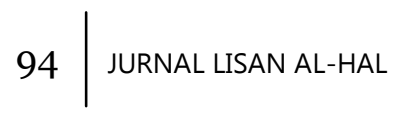


adalah seorang ulama yang selalu mengarang, berdiskusi, dan berijtihad. Ia telah menjadi salah seorang ulama besar pada bidang tafsir, hadist, fikih, ushul fikih, tauhid dan ilmu bahasa arab ", 2) Imam Maraghi mengatakan, " Ia adalah seorang ahli ushul fikih, hadist, nahwu, sastra, dan pidato"; dan 3) Imam Alusi mengatakan, " Ia adalah seorang ahli tafsir, nahwu, ushul fikih, dan tauhid" 34 .

Penguasaan beliau atas berbagai macam cabang ilmu dibuktikan dengan banyaknya karangan yang beliau tulis. Karangan-karangan beliau, menurut sebagian riwayat, mencapai 96 karangan. Diantara karangannya adalah i'lamu al-muwaqqi'in 'an rabb al-'Ālamin, ighāsiu al-lafahān min mașāid al-syaițān, Zād al-Ma'ād fi hadyu khoiri al-Ibād, Syifāu al-'Alil fi masāil al-qadlā' wa al-Qadar wa al-Hikmah wa al-Ta'lil, al-Thuruq alhukmiyyah fi siyāsah al-syar'iyyah, dll.

Tidak hanya karangan beliau yang mengagumkan, beliau juga memiliki murid-murid yang sangat diakui keilmuannya, semisal Ibnu Rajab al-Hanbali, Ibnu Katsir al-Syafi'i, al-Subki, al-Dzahabi, dll. Namun begitu, Ibnu Qayyim pernah merasakan dipenjara, dihina dan diarak berkeliling bersama gurunya Ibnu Taimiyah sambil didera dengan cambuk di atas seekor unta. Hal itu disebabkan karena dia menentang adanya anjuran agar orang pergi berziarah ke kuburan para wali. Setelah Ibnu Taimiyah wafat, Ibnu Qayyim pun dilepaskan dari penjara.

Ibnu Qayyim wafat pada malam Kamis tanggal 13 Rajab $751 \mathrm{H}$ dalam usia 60 tahun. Jenazah beliau disalatkan dua kali yakni di masjid jami' umawiy dan masjid jami' jirah karena banyak sekali orang yang ingin mengantarkannya. Beliau dikuburkan di al-bab al-shagir Damaskus bersebelahan dengan makam ibunya ${ }^{35}$.

\section{Biografi Fahmi Huwaidi}

Nama lengkap beliau adalah Mahmud Fahmi Abdul Razzaq Huwaidi. Beliau lahir di Giza pada tanggal 29 Agustus 1937 M. Dalam pendidikan beliau adalah lulusan dari Fakultas Hukum , Universitas Kairo pada tahun 1960 M. Beliau dikenal sebagai salah satu pemikir kontemporer asal Mesir. Sebagai seorang penulis produktif, beliau telah menerbitkan beberapa buku yang berkonsentrasi terhadap persoalanpersoalan hukum diantaranya Al-Qur'ān wa al-Sulțān, al-Islām wa alDimuqarāṭiyyah, Muwāținūn la Żimmiyyūn, iḥqāqu al-Haq, dll. Selain

\footnotetext{
hlm. 53

${ }^{34}$ Ibnu Qayyim al-Jauziyyah, Ahkāmu Ahli al- Żimmah (t.t. : Ramādi al-Nasyr, 1997),

35 Ibid, hlm. 77.
} 
menulis, beliau juga berkerja pada bagian kajian surat kabar Al-Ahram Kairo sejak tahun 1958 sampai tahun 1965. Pada tahun 1976, ia menjadi pimpinan redaksi majalah Al-'Arabiy Al-Kuwaitiyyah.

\section{Interaksi Politik Antara Muslim dengan Non-Muslim menurut Ibnu Qayyim dalam dār al-Islām}

a. Jizyah sebagai bentuk kehinaan orang kafir

Sebagai kelompok non-muslim yang berdiam di dār al-Islām, mereka diharuskan untuk membayar kompensasi yang disebut jizyah. Kompensasi ini menurut Ibnu Qayyim adalah sebagai bentuk kerendahan dan kehinaan terhadap orang kafir ${ }^{36}$. Jizyah menurutnya (mengikuti pendapat Abu Ya'la Al-Mawardi), adalah berasal dari kata jazā' yang berarti pembalasan. Pembalasan yang dimaksud ialah pembalasan dari kekufuran karena jizyah adalah sebuah kehinaan bagi orang kafir atau pembalasan kepada orang islam karena ia telah memberikan keamanan ${ }^{37}$. Perkataan Ibnu Qayyim ini berlandaskan pada firman Allah:

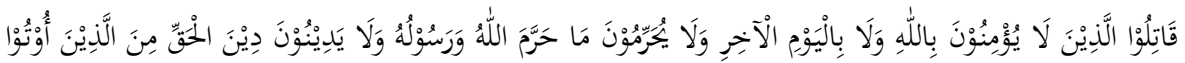

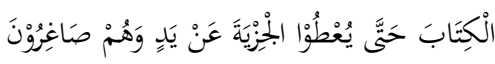

"Perangilah orang-orang yang tidak beriman kepada Allah dan tidak (pula) kepada hari kemudian, dan mereka tidak mengharamkan apa yang diharamkan oleh Allah dan Rasul-Nya dan tidak beragama dengan agama yang benar (agama Allah), (yaitu orang-orang) yang diberikan Al-Kitab kepada mereka, sampai mereka membayar jizyah dengan patuh sedang mereka dalam keadaan tunduk".

Menurut Ibnu Qayyim, kata 'an yadin disana bermakna dalam keadaan terhina dan terpaksa. Beliau juga menambahkan bahwa di akhir ayat, orang non-muslim disifati dengan kata "wa hum shāgirūn" yakni hina dan kecil. Makna "shāgir" dalam ayat diatas ialah orang-orang non-muslim terkena kewajiban untuk menjalankan ajaran-ajaran agama dan membayar jizyah.

Pendapat Ibnu Qayyim ini bertentangan dengan pendapat ulama lain (Syāfi'iyyah) yang mengatakan bahwa jizyah adalah kompensasi untuk menetap di dār al-Islām. Ibnu Qayyim mengemukakan beberapa alasan bahwa jizyah adalah sebagai bentuk penghinaan terhadap orang nonhlm. 122

36 Ibnu Qayyim al-Jauziyyah, Aḥkāmu Ahli al- Żimmah (t.t. : Ramādi al-Nasyr, 1997), hlm. 119

37 Ibnu Qayyim al-Jauziyyah, Aḥkāmu Ahli al- Żimmah (t.t. : Ramādi al-Nasyr, 1997),

96 JURNAL LISAN AL-HAL 
muslim. Pertama, jika Jizyah adalah sebuah kompensasi, maka jizyah juga berlaku bagi wanita, anak-anak, orang tua, dan orang buta. Kedua, jika memang jizyah adalah kompensasi, maka jizyah akan dibatasi dengan waktu, sebagaimana yang terjadi dalam akad sewa. Ketiga, jikalau memang demikian, niscaya nominal jizyah akan disesuaikan dengan manfaat yang didapat. Padahal, harga sewa rumah satu tahun adalah lebih banyak berpuluh-puluh kali lipat dari jumlah jizyah yang ditetapkan ${ }^{38}$.

\section{b. Pemerintahan tidak menerima kekufuran}

Ibnu Qayyim dalam kitabnya "Aḥkāmu ahli Żimmah" berpendapat bahwa pemerintahan Islam adalah sesuatu yang mulia. Oleh karena itu ia tidak akan pernah bercampur dengan kehinaan seperti kekufuran. Ia juga mengatakan bahwa keimanan seorang muslim tidak akan sempurna kecuali apabila ia telah terbebas dari kepemimpinan non-muslim ${ }^{39}$.

Ketika orang islam di dalam dār al-Islām memberikan kekuasaan terkait urusan-urusan negara Islam terhadap non-muslim, maka seolaholah kelompok non-muslim tersebut adalah sebagian dari orang-orang Islam. Hal ini sebagaimana yang termaktub dalam surat al-Maidah ayat 51 yang berbunyi :

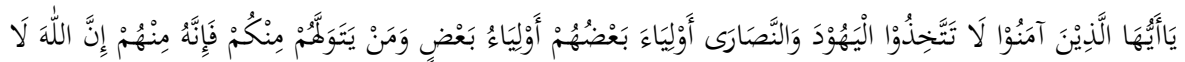

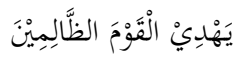

"Hai orang-orang yang beriman. Janganlah kamu mengambil orang-orang Yahudi dan Nasrani menjadi pemimpin-pemimpin(mu). Sebahagian mereka adalah pemimpin bagi sebagian yang lain. Barangsiapa diantara kamu mengambil mereka menjadi pemimpin, maka sesungguhnya orang itu termasuk golongan mereka. Sesungguhnya Allah tidak memberi petunjuk kepada orang-orang yang zalim. "

Disamping itu, kelompok non-muslim dalam pandangan Ibnu Qayyim adalah kelompok yang banyak melakukan tipu daya,

38 Untuk menentukan nominal jizyah ,para ulama' berbeda pendapat . Menurut Imam Syafi'i , jumlah nominal dilihat dari kemampuan ekonomi non-muslim. Bagi yang miskin cukup 1 dinar, bagi yang berkecukupan 2 dinar dan bagi yang kaya 4 dinar. Menurut Malikiyyah ,penentuan nominal tersebut diserahkan kepada Imam dengan catatan tidak lebih dari 4 dinar. Sedangkan Hanafiyyah berpendapat, bagi non-muslim yang miskin cukup dengan 12 dirham, non-muslim yang berkecukupan dengan 24 dirham dan bagi yang kaya 40 dirham. Ibnu Qayyim al-Jauziyyah, Ahkāmu Ahli al- Żimmah (t.t. : Ramādi al-Nasyr, 1997), hlm. 122. hlm. 499.

39 Ibnu Qayyim al-Jauziyyah, Aḥkāmu Ahli al- Żimmah (t.t. : Ramādi al-Nasyr, 1997), 
penghianatan, dan permusuhan kepada orang Islam. Oleh karena itu, di dalam Al-Qur'an terdapat banyak sekali ayat-ayat yang memperingatkan orang Islam tentang hal tersebut ${ }^{40}$. Jumlah seluruh ayatnya ada 33 ayat yang tersebar di beberapa surat, diantaranya:

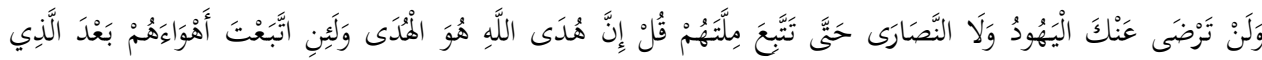

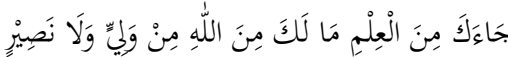

"Orang-orang Yahudi dan Nasrani tidak akan senang kepada kamu hingga kamu mengikuti agama mereka. Katakanlah: "Sesungguhnya petunjuk Allah itulah petunjuk (yang benar)." Dan sesungguhnya jika kamu mengikuti kemauan mereka setelah pengetahuan datang kepadamu, maka Allah tidak lagi menjadi pelindung dan penolong bagimu. "

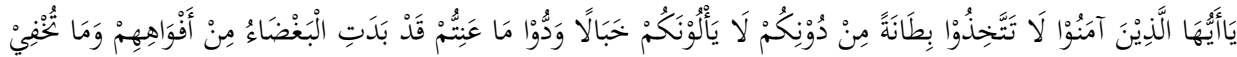

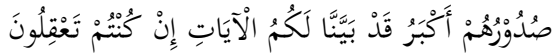

"Hai orang-orang yang beriman, janganlah kamu ambil menjadi teman kepercayaanmu orang-orang yang diluar kalanganmu (karena) mereka tidak henti-hentinya (menimbulkan) kemudaratan bagimu. Mereka menyukai apa yang menyusahkan kamu. Telah nyata kebencian dari mulut mereka, dan apa yang disembunyikan oleh hati mereka adalah lebih besar lagi. Sungguh telah Kami terangkan kepadamu ayat-ayat (Kami), jika kamu memahaminya."

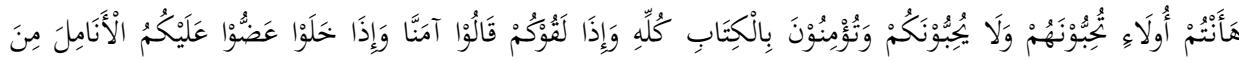

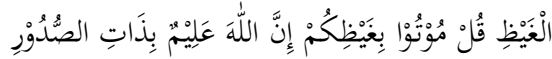

"Beginilah kamu, kamu menyukai mereka, padahal mereka tidak menyukai kamu, dan kamu beriman kepada kitab-kitab semuanya. Apabila mereka menjumpai kamu, mereka berkata "Kami beriman", dan apabila mereka menyendiri, mereka menggigit ujung jari antaran marah bercampur benci terhadap kamu. Katakanlah (kepada mereka): "Matilah kamu karena kemarahanmu itu." Sesungguhnya Allah mengetahui segala isi hati ."

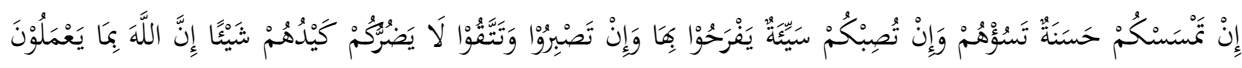

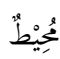

"Jika kamu memperoleh kebaikan, niscaya mereka bersedih hati, tetapi Jika hlm. 497.

${ }^{40}$ Ibnu Qayyim al-Jauziyyah, Aḥkāmu Ahli al- Żimmah (t.t. : Ramādi al-Nasyr, 1997),

98 JURNAL LISAN AL-HAL 
kamu mendapat bencana, mereka bergembira karenanya. Jika kamu bersabar dan bertakwa, niscaya tipu daya mereka sedikitpun tidak mendatangkan kemudaratan kepadamu. Sesungguhnya Allah mengetahui segala apa yang mereka kerjakan."

Tidak hanya Alquran yang melarang non-muslim untuk menduduki sebuah jabatan, Ibnu Qayyim juga memberikan hadis yang sejalan dengan apa yang ada dalam Alquran. Rasulullah bersabda ${ }^{41}$ :

$$
\text { إِنَّا لَا نَسْتَعِينُ بِمُشْرٍِ }
$$

"Sesungguhnya kami tidak meminta tolong kepada orang musyrik" (HR. Ibnu Majah)

Dalam sebuah hadist lain yang diriwayatkan oleh Imam Muslim diceritakan bahwasannya Rasulullah hendak pergi perang badar. Pada saat di tanah Wabarah, Rasulullah bertemu dengan seseorang yang terkenal dengan keberaniannya. Melihat kedatangannya, para sahabat bergembira. Seseorang tersebut lantas berkata, "Aku akan mengikutimu dan berperang bersamamu". Rasulullah bertanya, "Apakah engkau beriman terhadap Allah dan rasul-Nya?". Ia menjawab," Tidak". Kemudian Rasulullah bersabda, "Kembalilah. Sesungguhnya aku tidak akan meminta tolong kepada orang Musyrik"42.

\section{Interaksi politik antara Dār al-Islām dengan Dār al- Harbi}

Pada awalnya, Islam datang dengan cara sembunyi-sembunyi hingga akhirnya turun sebuah perintah untuk menyiarkan Islam secara terang-terangan. Dimulai dari mengajak sanak saudara untuk memeluk agama Islam dan akhirnya mengajak seluruh dunia untuk masuk islam.

Menurut Ibnu Qayyim, adanya tadrij (tahapan) dalam syiar Islam juga terdapat dalam hubungan muslim dengan non-muslim. Pada awalnya, orang Islam menjalin hubungan baik dengan non-muslim selama mereka juga berlaku baik. Oleh karena itu, peperangan hanya dilakukan sebagai bentuk pertahanan mereka terhadap serangan non-muslim. Namun, pada akhirnya umat islam diperintahkan untuk berperang melawan nonmuslim sehingga agama islam menjadi agama yang diikuti oleh semua orang.

Ibnu Qayyim menegaskan bahwa setelah turunnya ayat barāah (awal surat al-Taubah), orang non-muslim di dunia terbagi menjadi tiga

41 Muhammad al-Qazwaini, Sunan Ibnu Mājah (Beirut: Dar al-Kutub al-Ilmiyyah, t.th. ), vol. 2, hlm. 945.

42 Yahya bin Syaraf al-Nawawi, Șaḥih Muslim bi Syarḥi al-Nawāwi (Beirut : Dar alFikr 2004), vol. 6, hlm. 156. 
kelompok, kelompok ahlu Żimmah, ahlu șulhi wa hudnah, dan ahlu harb. Pada ayat barāah tersebut, Allah memerintahkan umat Islam untuk memerangi kelompok non-muslim hingga mereka beriman atau membayar jizyah. Disamping itu, umat Islam diperintahkan untuk melepaskan segala perjanjian dengan kelompok non-muslim. Kelompok non-muslim yang mempunyai perjanjian dengan orang Islam, maka harus ditunggu sampai habis masa perjanjian. Sedangkan kelompok non-muslim yang tidak mempunyai hubungan dengan orang islam, maka diberi waktu empat bulan. Baru setelah itu orang muslim dapat memeranginya.

\section{Interaksi Politik Antara Muslim dengan Non-Muslim menurut Fahmi Huwaidi dalam Dār al-Islām}

\section{a. Kesetaraan antara mayoritas dan minoritas}

Kesetaraan merupakan salah satu prinsip dalam interaksi politik Islam. Suatu prinsip yang mengharuskan pihak mayoritas untuk berbagi tempat dengan pihak minoritas. Dalam prinsip kesetaraan, dibutuhkan sebuah keadilan untuk menjaga tatanan kehidupan dan perasaan masyarakat umum (muslim) atau khusus (non-muslim) di wilayah dār alIslām.

Fahmi Huwaidi mengatakan bahwa untuk merealisasikan kesetaraan antara muslim yang mayoritas dengan non-muslim yang minoritas, dibutuhkan sebuah sikap dari masing-masing kelompok. Sikap pertama yang paling mendasar yakni adanya penghormatan kelompok mayoritas kepada perasaan kelompok minoritas. Ia mencontohkan sikap Khalifah Umar bin Khattab yang sangat menghargai kelompok minoritas. Dalam suratnya kepada Sa'ad bin Abi Waqash dikatakan, "Jauhkan pasukan muslim dari desa-desa (non-muslim) yang telah mengikat perjanjian aman maupun Żimmah. Dan janganlah orang-orangmu memasukinya kecuali apabila keberagamaannya dapat dipercaya. Dan juga jangan membuat perkara dengan mereka karena mereka mempunyai kehormatan dan perlindungan " 43 .

Sikap kedua yakni adanya kendali dalam menggunakan hak bagi kelompok minoritas sebagaimana kendali dalam menggunakan kebebasan. Kendali yang dimaksud adalah menghormati tatanan dan perasaan kelompok mayoritas. Dengan kata lain, kelompok non-muslim tidak boleh manyalahgunakan hak secara semena-mena sehingga

${ }^{43}$ Fahmi Huwaidi, Muwāthinūn la Żimmiyyūn (Kairo: Dār al-Syurūq, 1990), hlm. 147.

$100 \mid$ JURNAL LISAN AL-HAL 
menyakiti perasaan maupun tatanan masyarakat muslim ${ }^{44}$.

Adanya prinsip kesetaraan bagi kelompok non-muslim minoritas adalah untuk menolak diskriminasi bukan menafikan klasifikasi. Adanya klasifikasi muslim dan non-muslim dalam pemerintahan bukan berangkat dari keutamaan muslim atas non-muslim. Hal ini hanya untuk memenuhi syarat-syarat yang dibutuhkan untuk mengisi posisi-posisi tertentu ${ }^{45}$.

Ia membandingkannya dengan demokrasi yang ada di Amerika. Di Amerika terdapat slogan populer yang berbunyi majority rule, minority right (peraturan mayoritas dan hak minoritas). Namun begitu, dalam tradisi masyarakat Amerika, terdapat syarat khusus yang harus dimiliki seorang pemimpin. Seorang pemimpin Amerika harus mempunyai spesifikasi tertentu yang dikenal dengan W.A.S.P (White, Angelo, Saxon, and Protestan ).

\section{b. Non-Muslim dalam Jabatan Pemerintahan}

Sebagian ulama melarang kelompok non-muslim untuk menduduki kursi jabatan dalam dār al-Islām. Larangan ini didasarkan atas 3 ayat dalam Al-Qur'an yakni surat Ali Imran ayat 28 dan ayat 118 serta surat alMaidah ayat 51. Bahkan, menurut Prof. Torton dalam karyanya Ahlu Żimmah fi al-Islām mengatakan, "Dengan kedua ayat diatas, Khalifah Umar bin Abdul Aziz menulis surat kepada beberapa wakilnya di beberapa daerah untuk tidak memberikan kekuasaan kepada non-muslim dalam pemerintahan dār al-Islām"46.

Fahmi Huwaidi dalam bukunya, menolak pernyataan sebagian ulama ini. Menurutnya, pemahaman ketiga ayat yang dijadikan dasar larangan kelompok non-muslim untuk memiliki jabatan adalah salah. Ia melanjutkannya dengan memberikan penafsiran terhadap ketiga ayat tersebut. Ali Imran ayat 28

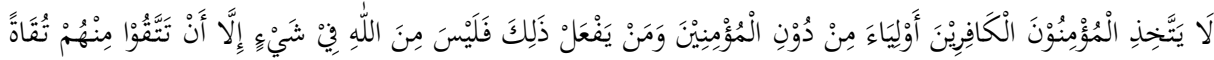

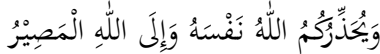

"Janganlah orang-orang mukmin mengambil orang-orang kafir menjadi wali dengan meninggalkan orang-orang mukmin. Barang siapa berbuat demikian, niscaya lepaslah ia dari pertolongan Allah, kecuali karena (siasat) memelihara diri dari sesuatu yang ditakuti dari mereka. Dan Allah

${ }^{44}$ Fahmi Huwaidi, Muwāthinūn la Żimmiyyūn..., hlm. 147.

45 Fahmi Huwaidi, Muwāthinūn la Żimmiyyūn..., hlm. 147.

46 Fahmi Huwaidi, Muwāthinūn la Żimmiyyūn (Kairo: Dār al-Syurūq, 1990), hlm. 157.

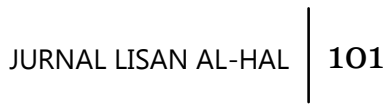


memperingatkan kamu terhadap diri (siksa)-Nya. Dan hanya kepada Allah kembali (mu). “

Fahmi mengatakan bahwa ayat ini melarang orang Islam untuk meminta tolong kepada orang kafir. Sehingga, karena orang Islam telah ditolong, orang Islam membantu orang-orang kafir mengalahkan orang islam lainnya dan mengungkap aib-aibnya. Kecuali, apabila orang islam berada pada kekuasaan orang kafir. Kemudian pada surah Ali Imran ayat 118.

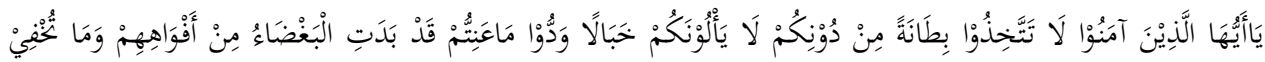

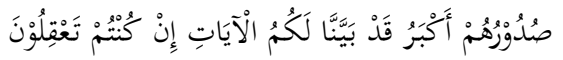

"Hai orang-orang yang beriman, janganlah kamu ambil menjadi teman kepercayaanmu orang-orang yang diluar kalanganmu (karena) mereka tidak henti-hentinya (menimbulkan) kemudaratan bagimu. Mereka menyukai apa yang menyusahkan kamu. Telah nyata kebencian dari mulut mereka, dan apa yang disembunyikan oleh hati mereka adalah lebih besar lagi. Sungguh telah Kami terangkan kepadamu ayat-ayat (Kami), jika kamu memahaminya"

Pada ayat ini, Allah melarang orang Islam berteman akrab dengan orang kafir. Menurut Fahmi, orang kafir yang dimaksud pada ayat ini adalah orang kafir yang membenci atau dengki atau suka melakukan tipu daya terhadap orang islam. Rasyid Ridlo dalam tafsir al-Manār mengatakan apabila ada orang kafir yang mempunyai kesamaan dalam nilai-nilai agama dengan orang islam, maka tidak ada larangan untuk berteman dengannya ${ }^{47}$. Selanjutnya pada surat al-Maidah ayat 51

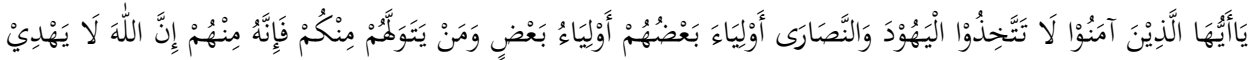

$$
\begin{aligned}
& \text { الْقَوَْ الظَّلَِلِيْنَ }
\end{aligned}
$$

"Hai orang-orang yang beriman, janganlah kamu mengambil orang-orang Yahudi dan Nasrani menjadi pemimpin-pemimpin(mu). Sebagian mereka adalah pemimpin bagi sebagian yang lain. Barangsiapa diantara kamu mengambil mereka menjadi pemimpin, maka sesungguhnya orang itu termasuk golongan mereka. Sesungguhnya Allah tidak memberi petunjuk kepada orang-orang yang zalim. "

Fahmi mengatakan ayat ini turun ketika kaum muslim berperang melawan kelompok Yahudi dan Nasrani. Di sisi lain, kelompok munafik 158.

${ }^{47}$ Fahmi Huwaidi, Muwāthinūn la Żimmiyyūn (Kairo: Dār al-Syurūq, 1990), hlm. $102 \mid$ JURNAL LISAN AL-HAL 
pada saat itu seperti Ubadah bin Shamit dan Abdullah bin Ubay melakukan musyawarah untuk membantu kelompok Yahudi dan Nasrani. Mereka takut jikalau umat Islam dikalahkan (karena pada saat itu kekuatan Yahudi dan Nasrani sangat kuat). Kemudian turunlah ayat ini sebagai peringatan kepada orang-orang yang masih lemah imannya untuk tidak condong dan menampakkan kecintaannya terhadap kelompok Yahudi dan Nasrani.

Fahmi menambahkan, hal ini tampak dari lanjutan ayat tersebut yang berbunyi:

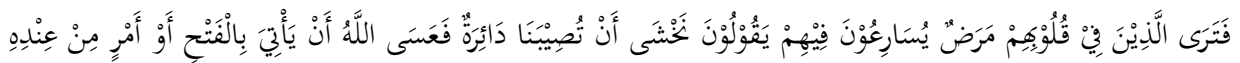

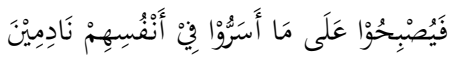

"Maka kamu akan melihat orang-orang yang ada penyakit dalam hatinya (orang-orang munafik) bersegera mendekati mereka (Yahudi dan Nasrani), seraya berkata: "Kami takut akan mendapat bencana." Mudah-mudahan Allah akan mendatangkan kemenangan (kepada Rasul-Nya), atau sesuatu keputusan dari sisi-Nya. Maka karena itu, mereka menjadi menyesal terhadap apa yang mereka rahasiakan dalam diri mereka"

Dalam sejarah, terdapat beberapa orang non-muslim yang pernah menduduki jabatan pemerintahan dār al-Islām. Pada masa al-Muntașir bi al-Allah dan al-Mu'tadid bi al-Allah, seorang nasrani dipercaya menjadi sekretaris panglima perang. Disamping itu, juga terdapat seorang nasrani yang menjadi panglima perang di Baghdad dan Andalusia pada saat dinasti Abbasiyyah ${ }^{48}$.

\section{Interaksi politik antara Dār al-Islām dengan Dār al-Harbi}

Pertama, Eksistensi Dār al-Harbi. "Apakah selain dār al-Islām tidak syar'i dan tidak ada hak untuk eksis di muka bumi ?, apakah harus (sebagai kewajiban agama) orang Islam memilih antara agama dan pisau di muka bumi? “. Inilah pertanyaan awal yang dilontarkan Fahmi Huwaidi dalam bukunya "Muwathinun la Dzimmiyyun". Pertanyaan ini muncul dari tulisan seorang orientalis bernama Bernard Louis. Dalam tulisannya ia menyatakan, " Telah ditemukan dalam diri orang-orang muslim dan orang-orang dunia lain, beberapa teks keagamaan dan perundangundangan yang mengharuskan adanya peperangan. Peperangan ini tidak akan selesai kecuali ketika seluruh dunia masuk ke dalam Islam atau tunduk kepadanya. Oleh karena itu, mustahil rasanya terdapat perjanjian 159.

48 Fahmi Huwaidi, Muwāthinūn la Żimmiyyūn (Kairo: Dār al-Syurūq, 1990), hlm.

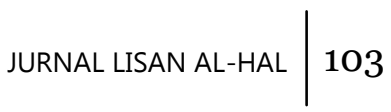


damai antara negara Islam dengan negara non-Islam secara syar'i. Oleh karena itu perang tidak akan pernah berhenti, yang ada hanyalah jeda saja baik karena darurat atau tindakan preventif " 49 . Pandangan ini seolah-olah menjustice bahwa agama Islam tidak menerima adanya perbedaan dalam hal akidah-kepercayaan.

Fahmi Huwaidi membantah pandangan ini. Pandangan ini jelasjelas merupakan sebuah pembacaan teks yang hanya setengah-setengah. Lebih lanjut ia mengatakan bahwa pada awal munculnya Islam, agama ini telah menerima adanya keyakinan-keyakinan diluar Islam baik dalam bentuk individu-individu maupun dalam bentuk negara-negara. Alquran sebagai pegangan pokok umat Islam telah mengatakan tentang adanya perbedaan keyakinan. Dalam beberapa surat Al-Qur'an dikatakan:

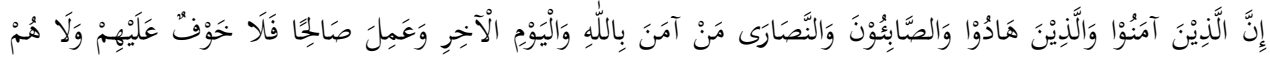

"Sesungguhnya orang-orang mukmin, orang-orang Yahudi, Șabiin dan orang-orang Nasrani, siapa saja (diantara mereka) yang benar-benar saleh, maka tidak ada kekhawatiran terhadap mereka dan tidak (pula) mereka bersedih hati."

$$
\text { لَكُمْم دِيْنُكُمْ وَلِيَ دِيْنِ }
$$

"Untukmu agamamu, dan untukkulah, agamaku "

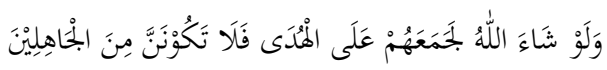

"Kalau Allah menghendaki, tentu saja Allah menjadikan mereka semua dalam petunjuk sebab itu janganlah sekali-kali kamu termasuk orang-orang yang jahil “

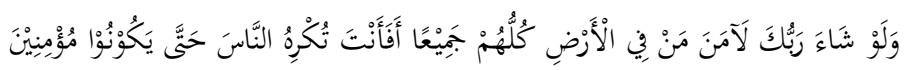

"Dan jikalau Tuhanmu menghendaki, tentulah beriman semua orang yang di muka bumi seluruhnya. Maka apakah kamu (hendak) memaksa manusia supaya mereka menjadi orang-orang yang beriman semuanya?"

Kesamaan akidah bukan sebagai syarat bagi keberlangsungan hidup dalam pandangan Islam dan takdir tuhan. Oleh karenanya perbedaan agama dan akidah tidaklah menjadi sebab untuk tidak mengakui eksistensi seseorang yang beragama lain. Alquran telah memberikan gambaran kecil mengenai hal ini dalam kisah antara Adam AS 217.

49 Fahmi Huwaidi, Muwāthinūn la Żimmiyyūn (Kairo: Dār al-Syurūq, 1990), hlm.

$104 \mid$ JURNAL LISAN AL-HAL 
dan Iblis. Dalam kisah tersebut, Iblis tidak mau mengikuti perintah tuhanNya sehingga ia menjadi kafir. Namun begitu, Allah tidak membinasakannya akan tetapi Dia hanya mengusir Iblis dari surga dan kelak akan dimintai pertanggung jawaban di Hari Akhir ${ }^{50}$.

Kedua, Peperangan melawan Dār al-Harby. Sebagian orang berpendapat bahwa Islam berdialog dengan dunia dengan pedang. Orangorang Islam seolah-olah digambarkan sebagai para penyamun bukan sebagai pemeluk agama yang bijaksana. Fahmi Huwaidi adalah salah seorang yang tidak setuju dengan pernyataan ini. Menurutnya, Islam adalah agama yang penuh dengan ajaran kedamaian dan keselamatan. Hidayah Islam oleh Alquran digambarkan dengan sesuatu yang mengantarkan ke jalan keselamatan. Allah berfirman:

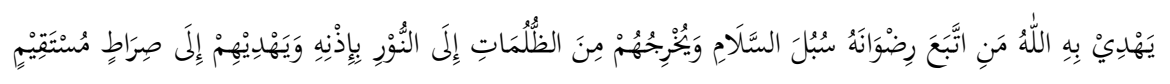

"Dengan kitab itulah Allah menunjuki orang-orang yang mengikuti keridaan-Nya ke jalan keselamatan, dan (dengan kitab itu pula) Allah mengeluarkan orang-orang itu dari gelap gulita kepada cahaya yang terang benderang dengan seizin-Nya dan menunjuki mereka ke jalan yang lurus."

Dalam Islam, hubungan yang terjalin antara masyarakat muslim dengan lainnya (non-muslim) adalah hubungan yang didasarkan atas keselamatan dan kedamaian bukan peperangan. Sekalipun dengan catatan, apabila mereka (non-muslim) juga cenderung kepada keselamatan. Hal ini dapat dilihat dari beberapa ayat, diantaranya:

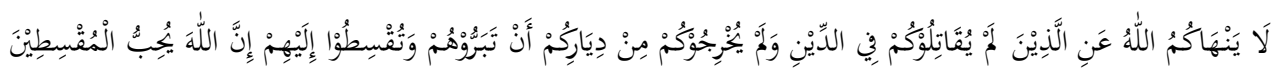

"Allah tidak melarang kamu untuk berbuat baik dan berlaku adil terhadap orang-orang yang tiada memerangimu karena agama dan tidak (pula) mengusir kamu dari negerimu. Sesungguhnya Allah menyukai orang-orang yang berlaku adil. “

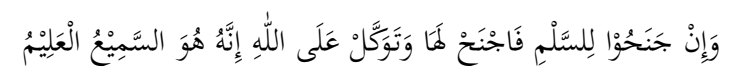

"Dan jika mereka condong kepada perdamaian, maka condonglah kepadanya dan bertawakkallah kepada Allah. Sesungguhnya Dialah Yang Maha Mendengar lagi Maha Mengetahui. "

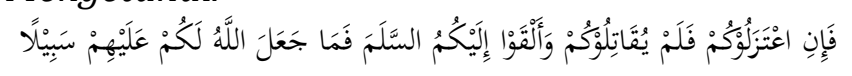
225 .

50 Fahmi Huwaidi, Muwāthinūn la Żimmiyyūn (Kairo: Dār al-Syurūq, 1990), hlm.

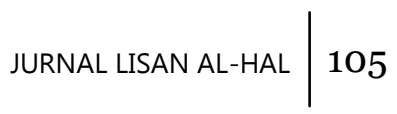


"Tetapi jika mereka membiarkan kamu, dan tidak memerangi kamu serta mengemukakan perdamaian kepadamu, maka Allah tidak memberi jalan bagimu (untuk menawan dan membunuh) mereka. "

Fahmi Huwaidi juga menambahkan, adanya peperangan dengan kaum non-muslim bukanlah merupakan sebuah pilihan melainkan sebuah paksaan yang sangat pahit. Oleh karena itu dikatakan dalam Al-Qur'an:

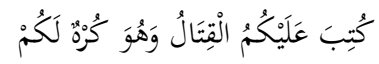

"Diwajibkan atas kamu berperang, padahal berperang itu adalah sesuatu yang kamu benci " Nabi juga pernah bersabda :

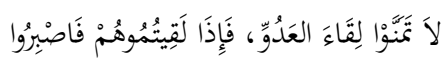

"Janganlah kamu berkeinginan untuk bertemu musuh. Jika engkau bertemu musuh, bersabarlah !" (HR.Bukhari)

Dalam sejarah Islam, memang dijumpai adanya instruksi perang kepada kafir harbi. Namun, instruksi ini bukanlah dalam rangka untuk menyampaikan risalah Muhammad SAW. Perang yang disyari'atkan dalam Islam adalah perang dalam rangka menangkis tindakan semena-mena yang dilakukan oleh non-muslim (difā'i). Fahmi mengatakan, dalam AlQur'an, ayat mengenai perintah perang datang bersamaan dengan larangan untuk penyerangan, berbuat lalim, dan aniaya ${ }^{51}$. Allah berfirman:

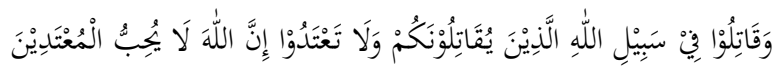

"Dan perangilah di jalan Allah orang-orang yang memerangi kamu, (tetapi) janganlah kamu melampaui batas, karena sesungguhnya Allah tidak menyukai orang-orang yang melampaui batas. "

Ayat diatas merupakan ayat terakhir yang turun mengenai ketentuan-ketentuan dalam perang. Dan juga, inti ayat ini sesuai dengan ayat pertama yang turun menyeru berperang, yakni surat Al-Hajj ayat 39 dan 40 yang berbunyi:

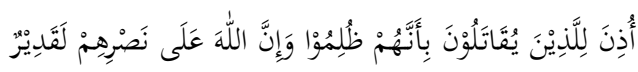

"Telah diizinkan (berperang) bagi orang-orang yang diperangi, karena sesungguhnya mereka telah dianiaya. Dan sesungguhnya Allah, benar-benar Maha Kuasa menolong mereka itu."

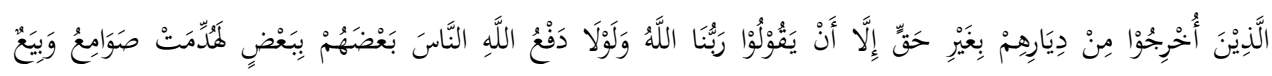
240.

51 Fahmi Huwaidi, Muwāthinūn la Żimmiyyūn (Kairo: Dār al-Syurūq, 1990), hlm.

106 JURNAL LISAN AL-HAL 


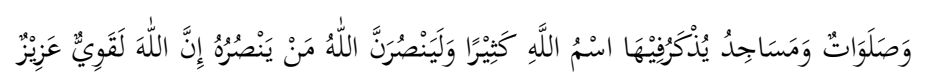

"(yaitu) Orang-orang yang telah diusir dari kampung halaman mereka tanpa alasan yang benar, kecuali karena mereka berkata: "Tuhan kami hanyalah Allah." Dan sekiranya Allah tiada menolak (keganasan) sebagian manusia dengan sebagian yang lain, tentulah telah dirobohkan biara-biara Nasrani, gereja-gereja, rumah-rumah ibadat orang Yahudi dan masjidmasjid, yang di dalamnya banyak disebut nama Allah. Sesungguhnya Allah pasti menolong orang yang menolong (agama)-Nya. Sesungguhnya Allah benar-benar Maha Kuat lagi Maha Perkasa,"

Fahmi Huwaidi juga menambahkan sebuah fakta sejarah yang menegaskan bahwa peperangan yang dilakukan oleh umat Islam adalah dalam rangka menangkis tindakan semena-mena yang dilakukan oleh nonmuslim (difä'i).

Pertama adalah perang badar. Setelah peristiwa hijrah yang dilakukan kaum muslimin, kelompok Quraisy semakin menjadi-jadi dalam mengganggu kaum muslim yang ada di kota makkah. Kaum muslimin sudah mencoba bersabar, namun dari hari ke hari, bukannya siksaan yang diterima mereda malah kian bertambah. Akhirnya, mereka memberanikan diri untuk meminta pertolongan kepada Allah dan kemudian turunlah ayat 75 surat Al-Nisa' yang memerintahkan golongan muhajirin dan anshor untuk menolong mereka.

Kedua adalah negara Habasyah. Negara Habasyah adalah negara non-muslim yang tak pernah diperangi umat Islam awal. Sekalipun pasukan muslim telah besar dan mampu mengimbangi kekuatan adidaya saat itu, mereka tidak pernah mendekati negara yang berada di wilayah etiopia tersebut. Menurut sejarah, muslim di Habasyah adalah muslim pertama yang berada di luar semenanjung arab. Negara Habasyah telah memberikan perlindungan dan kebebasan umat islam untuk menegakkan syiar disana. Oleh karena itu , negara ini tetap menjadi negara Nasrani ${ }^{52}$.

\section{E. Simpulan}

Setelah melalui tahapan-tahapan penelitian, penulis mendapatkan beberapa kesimpulan terkait dengan interaksi politik antara muslim dengan non-muslim menurut Ibnu Qayyim al-Jauziyyah dan Fahmi Huwaidi sebagai berikut: Pertama, Interaksi politik antara muslim dengan non-muslim dalam dār al-Islām. Menurut Ibnu Qayyim, interaksi politik ini bersifat diskriminatif yakni umat islam berada di posisi utama dan orang249.

52 Fahmi Huwaidi, Muwāthinūn la Żimmiyyūn (Kairo: Dār al-Syurūq, 1990), hlm.

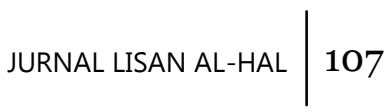


orang non-muslim berada di posisi kedua. Sifat diskriminatif tersebut dapat dilihat dari kewajiban jizyah dan larangan menduduki jabatan pemerintahan bagi orang-orang non-muslim.

Menurut Fahmi Huwaidi, interaksi politik ini bersifat egalitarian yakni umat Islam dan orang-orang non-muslim berada pada derajat yang sama. Sifat egalitarian tersebut dapat dilihat dari penghapusan status Żimmah bagi kelompok non-muslim dan hak menduduki jabatan pemerintahan bagi orang-orang non-muslim. Kedua, Interaksi politik antara Dār al-Islām dengan Dār al-Harb Menurut Ibnu Qayyim, dasar interaksi politik ini adalah peperangan. Menurut Fahmi Huwaidi, dasar interaksi politik ini adalah keselamatan.

\section{DAFTAR PUSTAKA}

Abdul Karim al-Syahrastani, Al-Milal wa al-Nihal. Beirut : Dār al-Fikr, 2005. Abdul Qahir al-Baghdadi, Al-Farqu Baina al-Firāq. Kairo : Maktabah Ibnu $\operatorname{Sin} \bar{a}$, t.th.

Abdurrahman bin Muhammad Ba'alawi, Bughyah al-Mustarsyidin. Beirut : Dar al-Kutub al-Ilmiyyah, 2013.

Abu Zahrah, Muhammad. Al-'Alāqah al-Dauliyyah fi al-Islām. Kairo: Dār alFikr al-'Arabi, 1995.

Ahmad bin Hajar al-'Atsqalani , Fathul Bāri bi Syarh Șahịh Bukhāri. Beirut : Dar al-Fikr. vol. 15. 2000.

Ali bin Muhammad al-Mawardi Al-Aḥkāmu al-Sulthāniyyah. Beirut : Dār alFikr, t.th.

Budiardjo, Miriam. Dasar-Dasar Ilmu Politik. Jakarta: Prima Grafika, 2015.

Hassan Shadily, Ensiklopedi Indonesia. Jakarta : PT. Dai Nippon Gitakarya Printing, 1984.

http://m.news.viva.co.id

Huwaidi, Fahmi. Muwāthinūn la Żimmiyyūn. Kairo: Dār al-Syurūq, 1990.

Ibnu Jarir at-Thabari, Jāmi' al-Bayān 'an Takwil āyi al-Qurān. Beirut : Dār al-Fikr, vol.14. 1995.

Ibnu Qayyim al-Jauziyyah, Aḥkāmu Ahli al- Żimmah. t.t. : Ramādi al-Nasyr, 1997.

Izzat al-Khayyath, Abdul Aziz. Al-Nidzām al-Siyāsi fi al-Islām. Kairo: Dār alSalām 1999.

Muhammad al-Qazwaini, Sunan Ibnu Mājah. Beirut: Dar al-Kutub alIlmiyyah, t.th.

Muhammad al-Shan'ani, Subul al-Salam. Kairo: Maktabah al-Iman, vol. 3. t.th.

108 JURNAL LISAN AL-HAL 
Muhammad bin 'Isa, Sunan al-turmudzi. Beirut: Dār al-Fikr, Vol 4. 1994.

Muhammad bin Mukran al-Anshari, Lisānul 'Arab. Beirut: Dār al-Kutub al'Ilmiyyah, vol. 6. 2003.

Oxford University Press, Oxford Learner's Pocket Dictionary. t.t. : t.p. t.th.

Qardlawi, Yusuf. Al-Khașaish al-'Āmmah li al-Islām. Beirut: Muassasah AlRisālah, 1983.

Min Fiqh al-Daulah fi al-Islām. Kairo: Dar al-Syuruq, 1997.

Sahal Mahfudz, Muhammad Ahmad. Nuansa Fiqh Sosial. Yogyakarta : LkiS, 2003.

Shihab, M.Quraish. Wawasan Al-Quran. Bandung: Penerbit Mizan, 2004.

Wahbah al-Zuhaili, Al-Fiqh al-Islāmi wa Adillatuhū. Damaskus : Dār al-Fikr, 2004.

------------, al-Tafsir al-Munir. Damaskus : Dār al-Fikr, vol. 15. 2011.

, Al-'Alāqah al-Dauliyyah fi al-Islām. Damaskus: Dār al-Maktabi, 2000.

Yahya bin Syaraf al-Nawawi ,Minhāju al-Thālibin wa 'umdah al-Muftin. Beirut: Dār al-Kutub al-'Ilmiyyah 2011.

-----------, Sahih Muslim bi Syarḥi al-Nawāwi. Beirut : Dar al-Fikr 2004.

Zakariyya al-Nadaf, Muhammad. Al-Akhlāq al-Siyāsiyah. Damaskus: Dār alQalam 2006.

Zidan, Abdul Karim. Ahkāmu al- Żimmiyyūn wa al-Mustakminun fi dār alIslām. Beirut: Muassasah al-Risālah, 1982. 
"Kepemimpinan Non Muslim"

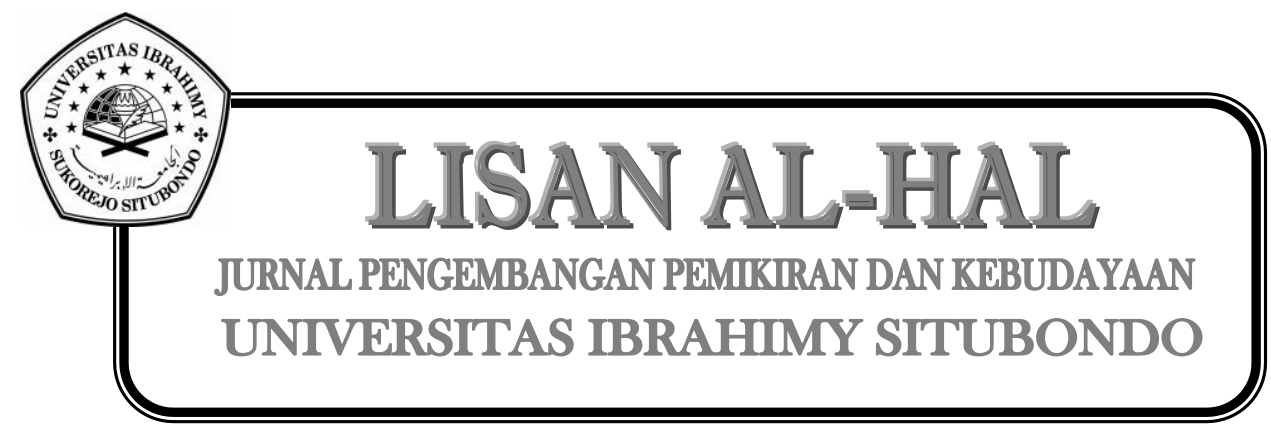

110 JURNAL LISAN AL-HAL 